\title{
Effect of Principal's Transformational Leadership Style on Teacher Performance
}

\author{
Bekti Rahayu1,a, Fahmi Idris ${ }^{1, b}$, Tuti Herawati ${ }^{1, c}$ \\ Postgraduate of Basic Education, Universitas Negeri Jakarta, Jakarta, Indonesia \\ Jalan Rawamangun Muka, Rawamangun, Jakarta Timur \\ a bekti.rahayu2593@gmail.com; b fahmiidris@unj.ac.id; c tutiherawati@unj.ac.id; \\ ${ }^{*}$ Corresponding Author
}

How to Cite : Rahayu, B., Idris, F., Herawati, T. (2019). Effect of Principal's Transformational Leadership Style on Teacher Performance. International Journal for Educational and Vocational Studies, 1 (5), 392-395

\section{ARTICLE HISTORY}

Received: 12 July 2019

Revised: 20 August 2019

Accepted: 20 September 2019

\section{KEYWORDS}

Agents of Change;

Teacher Quality;

Transformasional Leadership

\section{ABSTRACT}

The purpose of this study is to examine how Transformational Leadership is Teacher Performance. Research methods; descriptive analysis, quantitative approach, product moment correlation analysis techniques, determination and regression. Data collected through questionnaires. The population in this study were teachers in two elementary schools in East Bogor City, totaling 54 people, with a total sample of 34 respondents with simple random sampling technique. The results showed a significant relationship between transformational leadership and teacher teaching performance. The recommendation to improve teacher performance is to improve the dimensions of intellectual stimulation and the sensitivity of individual principals and teacher participation in training to improve teacher professional competence.

This is an open access article under the CC-BY-SA license.

\section{INTRODUCTION}

Education is an effort or activity to form intelligent human beings in various aspects, both intellectual, social, emotional, and spiritual, skilled and personable and can behave with noble character. Schools as formal education institutions are responsible for producing quality human resources. Formal education in schools does not only form the ability of thinking power, reasoning and the ability to power students' logic and evaluate themselves, after interacting totally in the social environment both in the school environment, and outside of school. Education in schools is not only limited to student learning outcomes, but also concerns student characteristics, images and self-confidence.

School education refers to four individual student achievements which include: (1) academic ability, (2) social ability, (3) participation ability, and (4) student success in the economy. The task of a teacher as a profession includes 3 aspects, namely: educating, teaching, and training. Educating means continuing and developing science and technology, teaching means conveying knowledge to students while training has meaning in developing skills (Hamalik, 2011)
In order for the school education process to be good, of course teaching staff who are qualified, have loyalty and good teaching performance. Teacher's high teaching performance will be very helpful in efforts to achieve goals, while to realize good performance it is necessary to have a leader who is truly competent in carrying out the duties and responsibilities in running school management, namely the work process with and through (utilizing) people others to achieve organizational goals efficiently (Ministry of National Education, 2001).

Education that is able to provide positive creative cultural values is able to think critically to achieve expected expectations. Changes in education are required to lead to better ones that can be done with various abilities that exist in acquiring knowledge and various values or norms of real life. But the passion for change does not stop until the discourse has to be developed in quality and quantity. The expected process in learning is ideally for the interaction of teachers and students fun.

The commitment of the Indonesian nation in the field of education since the birth of the 1945 Constitution of the Republic of Indonesia is very noble, among others, is to educate the nation's life, because in Law Number 20 of 2003 concerning National Education Systems Article 2 and 3 it is stated that national education based on 
Pancasila and the 1945 Constitution of the Republic of Indonesia the function is to develop capabilities and form a dignified character and national civilization in order to educate the life of the nation.

The teacher is the best opportunity in education to play an active role and put himself as a professional educator in accordance with the demands of the community who are increasingly critical in their attitude. Teachers are not merely teaching in providing their knowledge but also as educators who provide moral values and character as well as mentors who provide demands and strong character that will influence the success of teachers in learning to improve the quality of education.

To improve the quality of teachers, the government has made Law No. 14 of 2005 concerning teachers and lecturers. As explained in article 8, it is explained that teachers must have academic qualifications, competencies, educator certification, physical and spiritual health, and have the ability to realize the objectives of national education. Qualified academic qualifications of teachers will produce quality students.

A teacher can be said to have high work motivation if he is satisfied with his job, has motivation, a sense of responsibility and enthusiasm. motivation is the attitude or behavior of a group of people to work together diligently and consequently in achieving goals with full responsibility and discipline, so that work can be carried out easily, what can be achieved is achieved.

One of the quality of education is influenced by the teaching performance of teachers in carrying out their duties and responsibilities, one mirror of improving the quality of education in schools is the achievement of teachers in improving the quality of graduates who are productive, with the spirit of high teacher teaching performance, 2013).

Performance or performance is defined as work performance, work performance, achievement of work, work results, or performance. Performance as an expression of ability based on knowledge, attitudes, skills, and motivation in producing a goal.

In reality teacher teaching performance still needs to be developed and improved, this is reinforced from a survey conducted by UNESCO, the quality of teachers in Indonesia is at level 14 of 14 developing countries. This shows that teacher performance competency in Indonesia is far from the expectations of an educator who is able to bring quality teachers (Bappenas, 2012).

Therefore, if the school wants the teacher to be able to carry out their duties with high teaching performance, then they must play a role in influencing teaching performance. Several factors that can influence teacher teaching performance are transformational leadership, attitudes, behavior, personality, knowledge, and competence (Margaret Dale, 2013). Of the several teacher teaching performance factors it is very important to improve the quality of education. Teacher performance is influenced by the organization (leadership) and psychological factors (motivation). In this case, researchers want to focus on transformational leadership as a model of teacher transformational leadership and leadership as work motivation.

Principal transformational leadership directly plays a role in teacher teaching performance. Through the principal's transformational leadership, all the resources owned can be well-moved, including the teaching performance of the teacher. In carrying out their leadership in school, the principal acts as a good mentor and educator for school residents, especially for teachers in carrying out teacher teaching performance.

The leadership must be able to encourage or motivate their subordinates by inspiring their creativity at work. Leadership (Leadership) is a process of influencing other people to work towards achieving organizational goals. In leadership there are leadership models namely autocratic leadership.

\section{METHODS}

This research is a quantitative study using observation, interviews, and questionnaires with path analysis. This study analyzes the influence of one variable on other variables. The variables to be examined are X1 principal transformational leadership and Y teacher performance.

The next step is to determine the method or method that will be used so that the hypothesis can be tested empirically. To do this, several steps are needed, such as determining population and sample, compiling research instruments, data collection techniques, data processing, data processing, and determining data analysis techniques. The method used in this research is descriptive method with a quantitative approach.

\section{RESULTS AND DISCUSSION}

The results of the study of the two variables studied were the teacher performance variable $(\mathrm{Y})$, transformational leadership (X) was conducted before the instrument trial. The instrument trial was tested on 34 teachers consisting of 18 private teachers and 16 state teachers in East Bogor sub-district. From the results of trials on transformational leadership variables consisting of 60 items that were tested with results as many as 36 items that were declared valid or $60 \%$ and the reliability coefficient was 0.896 .

\begin{tabular}{|l|l|l|l|l|l|l|}
\hline No & $\begin{array}{l}\text { Variants that } \\
\text { were tested }\end{array}$ & $\begin{array}{l}\text { Amount of } \\
\text { Sample }\end{array}$ & $\mathrm{Dk}$ & $\mathrm{L}^{2}$ count & $\mathrm{L}_{\text {table }}$ & $\mathrm{a}(0.05)$ \\
\hline 1 & Y over $\mathrm{X}$ & 34 & 21 & 16,572 & $\begin{array}{l}32,6 \\
71\end{array}$ & Homogen \\
\hline \multicolumn{6}{|c|}{ Significant test $\mathrm{L}^{2}$ count $<\mathrm{L}_{\text {table }}$} \\
\hline
\end{tabular}

1. Normality Test of Estimated Raw Errors

Estimated standard error testing is done to determine 
whether or not a data distribution is normal, to test it using the Liliefors Test on teacher performance variables (Y) and transformational leadership variables $(\mathrm{X})$ with conditions if Ho $=\mathrm{L}_{\text {count }}>\mathrm{L}_{\text {table, }}$ means that the standard error is

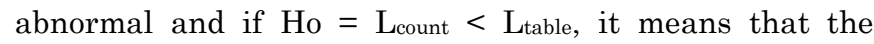
standard error is normal.

Table 2. Summary of Test for Normality Transformational leadership data with

\begin{tabular}{|l|l|l|l|l|}
\hline No & Standard Error & Lcount & Ltable & Conclusion \\
\hline 1 & Variabel $X$ dan $Y$ & 0,1362 & 0,15195 & Normal \\
\hline \multicolumn{5}{|c|}{$L_{\text {count }}$ Normal Terms $<$ Llable } \\
\hline
\end{tabular}

Based on the normality test using Liliefors obtained by $\mathrm{L}_{\text {count }}=0.13627$. The price is compared with the price of $\mathrm{L}_{\text {table }}=0.15195$ and the error rate of $5 \%$, then the data distribution of transformational leadership (X) with teacher performance $(\mathrm{Y})$ is normal.

\section{Test of Homogeneity Variance}

a. Test of homogeneity of Intelligence Data Variance (X) on teacher performance variable $(\mathrm{Y})$

$\mathrm{Ho}=\mathrm{L} 22_{\text {count }}<\mathrm{L} 22_{\text {table }}$ means the data variance is not homogeneous.

$\mathrm{Ho}=\mathrm{L} 2_{\text {count }}<\mathrm{L} 2_{\text {table }}$ means homogeneous data variance.

Table 3. Summary of Test Homogeneity of teacher performance $(Y)$ for transformational leadership $(X)$

\begin{tabular}{|c|c|c|c|c|c|c|}
\hline $\mathrm{N}$ & $\begin{array}{c}\text { Correlation } \\
\text { Coefficient }\end{array}$ & $\mathrm{Dk}$ & \multicolumn{2}{|c|}{$T_{\text {table }}$} & \multirow{2}{*}{$T_{\text {count }}$} & Conclusion \\
\cline { 3 - 5 } & $(\alpha=0,05)$ & $(\alpha=0,01)$ & & \\
\hline 34 & 0,970 & 32 & 4,15 & 7,50 & 9,045 & $\begin{array}{c}\text { Positive and } \\
\text { significant influence }\end{array}$ \\
\hline \multicolumn{6}{|c|}{ Level Requirements for Testing Significance of tcount $>$ ttable } \\
\hline
\end{tabular}

Scores on transformational leadership variables and scores on teacher performance have the same variant, so that both scores come from homogeneous populations.

The power of influence between transformational leadership variables $(\mathrm{X})$ and teacher performance $(\mathrm{Y})$ is shown by the correlation coefficient of 0.98 . The coefficient value if consulted with the interpretation table $r$ is in the coefficient interval of $0.800-1,000$, which means that the level of influence between the two research variables is very strong.

Testing the hypothesis "there is a positive influence between transformational leadership variables with variable teacher performance" using the significance test correlation coefficient with $\mathrm{t}$ test. The significance criteria for the correlation coefficient are if $t_{\text {count }}>t$ table, then the correlation coefficient is significant. Based on the results of calculations obtained $t=9.045$ with $t$ table $(\alpha=0.01)=7.50$ or t table $(\alpha=0.05)=4.15$. Thus, $t_{\text {count }}>t_{\text {table }}(\alpha=0.05)>t_{\text {table }}$ $(\alpha=0.01)=9,045>7.50>4.15$ which means the transformational leadership correlation coefficient with teacher performance is significant, so it is concluded that there is a positive influence and significant between transformational leadership and teacher performance. This can be seen in the table as follows:

Table 5. Results of Calculation of Significance Tests of Variable Correlations of Transformational Leadership (X) with Teacher Performance (Y)

\section{a. Correlation Coefficient Test}

Based on the correlation coefficient (rxy) between transformational leadership (X) and teacher performance (Y) is $\mathrm{r}=0.970$. This means that transformational leadership with teacher performance has a very strong influence level with intervals of $0.800-1,000$.

\section{b. Calculation of the coefficient of determination}

Based on the coefficient of determination (r2) between transformational leadership (X) and teacher performance (Y) is $\mathrm{r} 2=0.931$. This means that transformational leadership has a role in contributing $86.7 \%$ to teacher performance.

Based on the results of the calculation of statistical analysis above that there is a tendency score in transformational leadership where the average transformational leadership is 143.59. The results of a similar analysis found that the average score in teacher performance was 76.35 with the number and results of the study that with the interval coefficient the tendency of teacher performance in good schools with 10 or $29 \%$ teachers, it was stated that teachers had good teacher performance.

The average transformational leadership is 143.59 , the highest value is 160 and the lowest value is 124 , the level of tendency is high. The average teacher performance is 76.35. While the interpretation changes obtained from transformational leadership with teacher performance are worth 0.97 or $97 \%$ which is very high and can be stated that the relationship is very strong. The results of the analysis of hypothesis testing data obtained data that there is a positive relationship between the motivation of achievement on teacher performance. This shows that the research hypothesis is accepted, meaning transformational leadership contributes to teacher performance.

Transformational leadership from the results of this study has been proven to be able to predict teacher performance by $97 \%$ or 0.970 . This means that transformational leadership is one of the most decisive factors in the success of teacher learning. Because transformational leadership becomes a driver as well as giving direction to the teacher, so that the objectives desired by the subject of learning can be achieved optimally (Sardiman, 2012).

Transformational leadership is very important in improving teacher performance. Teachers who can relate to their social environment will get recognition and support from others. As evidenced by the results of the calculation, there is a positive relationship between transformational 
leadership and teacher performance in statistical analysis indicated by the results of the significance test and regression with the regression equation $\hat{\mathrm{Y}}=(67.83+$ $0.473 \mathrm{x})$. This means that every increase in one unit of transformational leadership variables will cause an increase in teacher performance by 0.931 units.

The strength of the relationship between transformational leadership and teacher performance is indicated by a correlation coefficient of 0.970 . The price coefficient shows that there is a very strong relationship between transformational leadership and teacher performance. The magnitude of the contribution of transformational leadership to teacher performance is shown by the coefficient $\left(\mathrm{r}^{2}\right)$ of 0.931 with a coefficient of determination of $86.7 \%$. This means that the increase or decrease in teacher performance is influenced by the level of transformational leadership of $86.7 \%$, while the remaining $13.3 \%$ is influenced by other factors.

The positive relationship between transformational leadership and teacher performance based on this study is shown from statistical analysis which results in regression significance $\mathrm{F}_{\text {count }}<\mathrm{F}_{\text {table }}(\mathrm{a}=0.05)<\mathrm{F}_{\text {table }}(\mathrm{a}=0.01)=0.813$ $<2.33<3.30$. This shows the relationship between transformational leadership and teacher performance, while the coefficient of determination (KD) $86.7 \%$ obtained objective information that there is a relationship between transformational leadership and teacher performance.

Based on the description above, it can be concluded that there is a relationship between transformational leadership and teacher performance. Thus, it shows a positive influence between transformational leadership on teacher performance.

\section{CONCLUSION}

It can be concluded that there is a positive influence between transformational leadership and teacher performance, which means the higher the level of transformational leadership the higher the teacher's performance, and vice versa the lower the level of transformational leadership of the principal, the lower the teacher's performance.

The influence can be seen from the correlation coefficient $r$ of 0.970 which means that the influence between variables is very strong. The regression equation coefficient $\hat{\mathrm{Y}}=67.83+0.473 \mathrm{x}$ which means that each increase in one transformational leadership unit will increase teacher performance by 0.473 units. The contribution of transformational leadership variables in improving teacher performance is 0.867 or as much as $86.7 \%$ and the remaining $13.3 \%$ can be influenced by various other factors.

\section{REFERENCES}

Bush, T. (2008). Manajemen strategis kepemimpinan pendidikan. Jogjakarta: IRCiSoD

Danim, Suparno. (2013). Manajemen dan Kepemimpinan Transformasional Kepala Sekolah. Jakarta: Rineka Cipta

Dale, Margaret (2003), Management - Study and teaching. Jakarta: Gramedia

Han, J. and H. Yin (2016). "Teacher motivation: Definition, research development and implications for teachers." Cogent Education 3(1): 1217819.

Hamalik, Oemar. (2011). Kurikulum dan Pembelajaran. Jakarta: Bumi aksara

Hasibuan. (2005). Manajemen Sumber Daya Manusia. Jakarta: Bumi Aksara

Ilyas Yaslis. (2005). Kinerja Teori dan Penelitian. Yogyakarta: Liberty

Mangkunegara, Anwar Prabu. (2014). Manajemen Sumber Daya Manusia. Bandung: Remaja Rosdakarya

E Mulyasa. (2013) Uji kompetensi dan Penilaian Kinerja guru. Bandung: PT Remaja Rosdakarya

Peraturan Pemerintah No. 19 Tahun 2005 tentang Standar Nasional Pendidikan pasal 28 ayat (3)

Syafaruddin. (2010). Kepemimpinan Pendidikan. Jakarta: Quantum Teaching

Sanjaya, Wina. (2008). Kurikulum dan Pembelajaran: Teori dan Praktik Pengembangan Kurikulum Tingkat Satuan Pendidikan (KTSP). Jakarta: Prenada Media Group.

Sardiman, A.M. (2012). Interaksi dan Motivasi Belajar Mengajar. Jakarta: PT Raja Grafindo Persada 